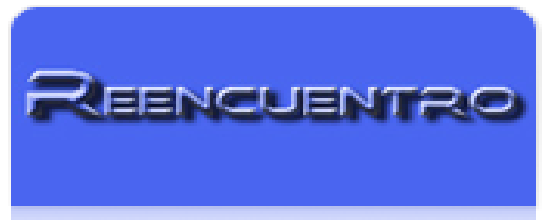

Reencuentro

ISSN: 0188-168X

cuaree@correo.xoc.uam.mx

Universidad Autónoma Metropolitana Unidad Xochimilco

México

Karseth, Berit

Qualifications frameworks for the European Higher Education Area. A new instrumentalism or "much ado about nothing"?

Reencuentro, núm. 58, agosto, 2010, pp. 6-16

Universidad Autónoma Metropolitana Unidad Xochimilco

Distrito Federal, México

Available in: http://www.redalyc.org/articulo.oa?id=34014049002

How to cite

- Complete issue

- More information about this article

Journal's homepage in redalyc.org

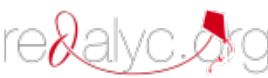

Scientific Information System Network of Scientific Journals from Latin America, the Caribbean, Spain and Portugal Non-profit academic project, developed under the open access initiative 


\section{Qualifications frameworks for the European Higher Education Area A new instrumentalism or "much ado about nothing"?"}

BERIT KARSETH*

\begin{abstract}
The purpose of this article is to explore the development of qualifications frameworks as a key element in the Bologna process, which aims to develop a European Higher Education Area by 2010. By setting up descriptors of learning outcomes, a European qualifications framework is intended as an instrument that enables Europe to coordinate and exchange qualifications. Furthermore, the article analyses the proposal of a national qualifications framework in Norway and institutional responses to it. Despite general support for the idea of a framework, the analysis shows that the institutions question the possibility of a qualifications framework that fits all types of educational programmes. With reference to curriculum theory the article concludes that the idea of a qualifications framework based on measurable learning outcomes represents a turn towards an instrumental curriculum approach in higher education, in contrast to a traditional curriculum approach which foregrounds disciplinary content and its mastery. Drawing on institutional theory the article also questions the possible impact of qualifications frameworks in higher education.
\end{abstract}

Keywords: Qualifications frameworks / higher education / curriculum theory / Bologna process.

\begin{abstract}
RESUMEN
El propósito de este artículo es explorar el desarrollo del marco de calificaciones como un elemento clave en el proceso de Bolonia, cuyo objetivo es desarrollar el Área Europea de Educación Superior para el año 2010. Con la creación de los descriptores de resultados de aprendizaje, el Marco Europeo de Calificaciones es concebido como un instrumento que permite a Europa coordinar e intercambiar calificaciones. Por otra parte, el artículo analiza la propuesta de un marco nacional de calificaciones en Noruega y las respuestas institucionales a la misma. A pesar de apoyo general a la idea de un marco, el análisis muestra que las instituciones ponen en tela de juicio la posibilidad de un marco de calificación que se adapte a todo tipo de programas educativos. Con referencia a la teoría curricular el artículo concluye que la idea de un marco de calificaciones basado en medir los resultados de aprendizaje representa un giro hacia un plan de estudios instrumentales en la educación superior, en contraste con el enfoque tradicional que pone en primer plano los contenidos disciplinarios y su dominio. Basándose en la teoría institucional del artículo también se pregunta sobre el posible impacto de los marcos de calificaciones en educación superior.
\end{abstract}

Palabras clave: Marcos de calificación / Educación superior / Teoría curricular / Proceso de Bolonia.

\section{INTRODUCTION}

Within the entire sector of education, recognition of qualifications has become a core political issue in Europe. In 2007 the European Parliament agreed to the establishment of what has been called the European Qualifications Framework (EQF). The main purposes of the Framework are to promote mobility between countries and to facilitate lifelong learning. In the same year, ministers participating in the Bologna process committed themselves to implementing national qualifications frameworks by 2010, which would be certified against the overarching Framework for Qualifications of the European Higher Education Area (EHEA). The London meeting of the Bologna process in 2007 stated that the ministers see the overarching framework "as a central element of the promotion of European higher education in a global context" (London Communiqué 2007, p. 3).

A central premise in both the European and national frameworks is the concept of learning outcomes and its role in defining educational objectives. The overall aim of this article is to analyse the substance of the idea of a qualifications framework by addressing the main characteristics of the curriculum approach on which the framework is based. In doing that, I will use the qualifications framework as a peep hole for looking into the processes of curriculum restructuring going on in European higher education. In the end,

* Berit Karseth is Professor of Education, Institute for Educational Research, University of Oslo, Box 1092, Blindern, N-0317, Oslo, Norway. E-mail: berit.karseth@ped.uio.no 1. This text is a reprint of an article published in the journal Learning and Teaching: The International Journal of Higher Education and Social Sciences (LATISS) 2008 1(2), pp. 77-101. 
I present some critical comments on how the new language of higher education curriculum policy may affect the ability of the university to act as a place of critical thinking, plurality and open communication.

The development of qualifications frameworks on a European as well as on a national level deals with issues that represent the heartland of curriculum policy and curriculum practice. Consequently, I find curriculum theory a fruitful analytical point of departure given that qualifications take account of the prescribed learning objectives and learning outcomes of higher education. With the introduction of qualifications frameworks, curriculum issues that used to be dealt with on an institutional level have become political issues on a national and even supranational level. Implicitly and explicitly a framework indicates what ought to be the purpose, content, sequence and evaluation of a programme, which all represent central elements of the definition of curriculum.

The empirical point of departure is documents developed within the European policy context of the Bologna process. In addition, I follow the process into the Norwegian national scene by analysing the proposal of a national framework and institutional responses to it. Although on both a European and a national level, the qualifications frameworks address all tiers of education, here it is the ambition to develop a qualifications framework for higher education that is in the foreground.

\section{TOWARDS A COMMON QUALIFICATIONS FRAMEWORK FOR EUROPEAN HIGHER EDUCATION}

The identification of two main cycles -the bachelor's degree and the master's degree- within the Bologna Declaration (1999) may be seen as the first step towards a qualifications framework for the European Higher Education Area. However, it was in the communiqué from the Berlin meeting (2003) that the ministers explicitly called for an overarching framework. The communiqué states:

Ministers encourage the member States to elaborate a framework of comparable and compatible qualifications for their higher education systems, which should seek to describe qualifications in terms of workload, level, learning outcomes, competences and profile. They also undertake to elaborate an overarching framework of qualifications for the European Higher Education Area. Within such frameworks, degrees should have different defined outcomes. First and second cycle degrees should have different orientations and various profiles in order to accommodate a diversity of individual, academic and labour market needs. First cycle degrees should give access, in the sense of the Lisbon Recognition Convention, to second cycle programmes. Second cycle degrees should give access to doctoral studies (Berlin communiqué 2003, p. 4).
The Berlin meeting and the Bologna Follow-up Group (BFUG) asked the Bologna Working Group to further elaborate the qualifications framework. The group was asked to:

1. Identify reference points for national frameworks of qualifications (in terms of workload, level, learning outcomes, competences and profile), which may assist member states in establishing their frameworks.

2. Elaborate on an overarching framework of qualifications for the European Higher Education Area.

3. Establish key principles for frameworks of qualifications, both at national and European levels (Bologna Working Group on Qualifications Framework 2004, appendix 2, p. 52).

It was also stated that other policy areas should be taken into account including those within the Copenhagen process on vocational education and training and the wider Lisbon Agenda on creating the European Higher Education Area, and as articulated in the report from European Council and Commission Education and Training 2010

(European Council 2004). A first report from the Bologna Working Group was delivered in 2004 and a revised final version was finished in February 2005 (Bologna Working Group on Qualifications Framework 2005) and presented to the Bologna meeting in Bergen 2005. The report (about 100 pages excluding appendices) is rather detailed. It emphasises the importance of linking the qualifications frameworks to the objectives expressed in the Bologna documents where the most relevant issues, according to the report, are international transparency, recognition, and mobility (2005). The report concludes that a framework for qualifications of the EHEA should be regarded as a

meta-framework within which to develop national frameworks and, in broad terms, it stipulates the outline and boundary of national frameworks, and is a device, which helps to provide clearer understanding of how the qualifications made within the European higher education area are related to each other, especially where these national systems have themselves been incorporated into formal national frameworks. It offers a common set of cycles and levels, with descriptors for those cycles.... The framework for qualification of the EHEA does not replace national frameworks. It augments them by providing a series of reference points whereby they can demonstrate their mutual compatibility (Bologna Working Group on Qualifications Framework 2005, pp. 58-59).

As stated in the Berlin communiqué, learning outcomes are a key element of the Qualifications Framework. The report argues that while there is a long tradition in higher education of being explicit 
about the knowledge to be achieved, explicitness about skills or competence has been less developed (Bologna Working Group on Qualifications Framework 2005, p. 63). The learning outcome common to all holders of a particular type of qualification is expressed in the report as a "qualification descriptor" and the report proposes that the so-called Dublin Descriptors should be adopted (Bologna Working Group on Qualifications Framework 2005, p. 101). According to the report, the Dublin Descriptors offer a generic statement of typical expectations of achievements and abilities and it builds on the following elements:

1. knowledge and understanding

2. applying knowledge and understanding

3. making judgements

4. communication skills

5. learning skills

To give an example, according to the Dublin Descriptors a descriptor of communication skills that signifies completion of the first cycle (bachelor's degree) is "[the student] can communicate information, ideas, problems and solutions to both specialists and non-specialist audiences" (Bologna Working Group on Qualifications Framework 2005, p. 195).

The descriptors are neither, as the report points out, subject-specific nor limited to academic, professional or vocational areas. Therefore, as it goes on, "the descriptors should be read within the context and use of the language of that discipline" (Bologna Working Group on Qualifications Framework 2005, p. 65). In order to verify that national frameworks are compatible with the EHEA framework, the report proposes criteria which include that the national framework and its qualifications must be clearly based on learning outcomes, that the qualifications are linked to ECTS (European Credit Transfer System) credits and that the national framework is connected to the national quality assurance system (2005, pp. 102-103) Finally, the report stresses the centrality of the "national authority in the development of national frameworks and their associated instruments, and the importance of considering the EHEA framework, the Dublin descriptors, and the guideline ranges on ECTS credits as "reference points"" (2005, p. 105).

[original emphasis].

At the meeting in Bergen, the ministers agreed that generic descriptors for each cycle (including the third cycle, the PhD level) based on learning outcomes and competences, and credit ranges in the first and second cycles, should be adopted. Moreover, we can read that the ministers

... commit ourselves to elaborating national frameworks for qualifications compatible with the overarching framework for qualifications in the EHEA by 2010, and to having started work on this by 2007 . We ask the

Follow-up Group to report on the implementation and further development of the overarching framework. We underline the importance of ensuring complementarity between the overarching framework for the EHEA and the proposed broader framework for qualifications for lifelong learning encompassing general education as well as vocational education and training as now being developed within the European Union as well as among participating countries (Bergen Communiqué 2005).

Based on the Bergen meeting, the Working Group on the Qualifications Framework was asked to consider what further development of the framework was required. They were also asked to monitor the development of the European Qualification Framework for Lifelong Learning with the aim of ensuring complementarity between that framework and the EHEA framework (Bologna Working Group on Qualification Framework 2007, p. 41). From reading this report it is clear that the Bologna Process, and the process of the European Union (EU) to some extent, were intended to merge. The report recommends that the EU member states ask the European Commission to revise its proposal for ECVET (European Credit for Vocational Education and Training) in a way that builds on or relates to ECTS (p. 35). The report gives many recommendations related to the criteria established for the verification process. One is that there is a need to ensure that national verification reports address the issue of labour market relevance of the bachelor's degree (p. 38).

After the Bergen meeting a new Trends Report was delivered. One of the key findings reported is

National qualification frameworks are currently an aspirational rather than an actual tool for most systems. To be effective, they should be designed coherently with broad societal consultation and strong involvement of higher education institutions (Crosier, Purser \& Smidt 2007, p. 69).

As Adam pointed out in his introduction to the Bologna process seminar on recognition in Riga, 2007:

When developments in qualifications frameworks, cycles, learning outcomes, quality assurance, credits, recognition and lifelong learning are put together something new and powerful will be created. The European Higher Education Area (EHEA) will provide immense opportunities for countries and institutions providing they fully embrace the changes inherent within the new architecture for higher education that is emerging... However, it must be remembered that for most countries the difficult task of producing and implementing qualifications frameworks and learning outcomes is just commencing (Crosier, Purser and Smidt 2007, p. 69).

The vision, that can be read between the lines in this quote, is one of a coherent system where the different 
objectives of the Bologna process are related to each other in an appropriate and rational way.

In the report from the Bologna Working Group on Qualification Frameworks (2007) to the London meeting the establishment of two overarching frameworks, the Bologna framework (EHEA framework) and the European Qualification Framework (EQF), is discussed. It is stated that they will coexist and that they have different scopes and purposes and also use different methodologies (2007, p. 7). The group concludes in the following way:

The differences in scope and purpose make it clear that the two frameworks can't substitute each other but the group is satisfied that national qualifications frameworks compatible with overarching EHEA framework will also be compatible with the proposal from the European Commission on a European Qualifications Framework for Lifelong Learning (Bologna Working Group on Qualification Frameworks 2007, p. 8).

However, in order to avoid confusion by the existence of two overarching frameworks "the working group recommends that the promotion of European higher education outside Europe should build on the overarching EHEA-framework, which includes the Dublin descriptors"( 2007, p. 8). Finally then, this conclusion is followed up in the communiqué from the London meeting:

\footnotetext{
We note that some initial progress has been made towards the implementation of national qualifications frameworks, but that much more effort is required. We commit ourselves to fully implementing such national qualifications frameworks, certified against the overarching Framework for Qualifications of the EHEA, by 2010. Recognising that this is a challenging task, we ask the Council of Europe to support the sharing of experience in the elaboration of national qualifications frameworks. We emphasise that qualification frameworks should be designed so as to encourage greater mobility of students and teachers and improve employability. We are satisfied that national qualifications frameworks compatible with the overarching Framework for Qualifications of the EHEA will also be compatible with the proposal from the European Commission on a European Qualifications Framework for Lifelong Learning (London communiqué 2007, p. 3).
}

The next Ministerial Conference of the Bolgona process will be hosted by the BENELUX countries at the universities of Leuven and Louvain-la-Neuve in 2009.

Taken together there is an ambition advocated by ministers taking part in the Bologna process agreements to develop an instrument that enables Europe to coordinate its qualifications by setting up descriptors of learning outcomes and thereby reach the main objectives of the Bologna process: transparency, mobility and employability. Although it is argued that the two qualifications frameworks, the Bologna framework and the European Qualifications framework should be compatible, the documents from the Bologna Process underscore that there are tensions and important differences concerning purpose and scope.

\section{THE DEVELOPMENT OF A NATIONAL FRAMEWORK IN NORWAY}

In the report presented to the Bologna meeting in Bergen 2005 on the qualifications framework (Bologna Working Group on Qualifications Framework 2005) the relationship between the national framework and the overarching European qualifications framework is described:

... it is important to recognise that national frameworks will reflect the respective national discussions on the purposes of higher education and different agendas in higher education policy. To find the right balance between the diversities of national frameworks and the benefits of a close linkage between them is the main challenge for constructing an overarching framework (2005, p. 26) .

According to the Bologna Process Stocktaking Report (2007) the development of national frameworks of qualifications is one of the areas where there is still some way to go: "There may be confusion and even resistance to the notion of a national qualifications framework" (2007, p. 50). One explanation that the report gives for the delayed development is that there is some confusion between the two frameworks (EQF and HEEA).

Furthermore, in a report on the implementation of national qualifications frameworks Stephen Adam (2007) points to many concerns and problems associated with the development. Although optimistic, he describes some important experiences:

\footnotetext{
The creation of 'new style' qualifications frameworks, articulated with the overarching EHEA framework, based on levels/cycles, learning outcomes, qualifications descriptors, profile, credits, workload, etc. is clearly not a simple exercise. Such a process raises numerous issues and will only be fully completed and implemented after the 2010 deadline. Experience to date has highlighted problems and confusions associated with compatibility of frameworks, potential difficulties connected with the time-scale of the whole process and a distinct European regional imbalance in the level of national progress (Adam 2007, p. 18).
}

In Norway, in December 2005 a working group was appointed by the Ministry of Education and Research to consider the development of a National Qualifications Framework for higher education. The group presented a final report for consultation in 
April 2007 (Rapport fra en arbeidsgruppe 2007). The group consisted of nine persons from the ministry, NOKUT, the two main student organisations, and the Council of Higher Education. There were no representatives from academics or the higher education institutions.

With reference to Adam's report Using Learning Outcomes, the group defined a learning outcome as "a written statement of what the successful student/ learner is expected to be able to do at the end of the module/course unit, or qualification" (Rapport fra en arbeidsgruppe 2007, p. 17). Furthermore, the group argued that when the curriculum design of a programme is described through learning outcomes, the focus moves from the content (what to teach) to the outcome (what the students are able to do after they have finished a course (Rapport fra en arbeidsgruppe 2007, p. 19).

The proposal presented in the report recommends a framework that follows the three main cycles (bachelor's, master's, PhD). First, the formulations of the descriptors at programme level should include all performances that represent the grade pass or better. Second, the descriptors have to show progression between the cycles. Third, descriptors of learning outcome must be measurable. Fourth, the framework has to fit all higher education courses and finally the descriptors must be simple and understandable for everybody. The working group follows the distinction between knowledge, skills and competence put forward in the EQF rather than the Bologna framework that takes the five Dublin descriptors as the starting point (knowledge and understanding, applying knowledge and understanding, making judgement, communication skills, learning skills).

Below I give a few examples of descriptors recommended by the working group:
As mentioned above, the proposal was sent out for public consultation where higher education institutions together with other stakeholders were invited to send in their comments. While only 13 of 24 public university colleges sent their comments, six of the seven public universities did. In addition to thse I have looked at the remarks from two public institutes of the arts and the Norwegian academy of music, all in all 22 institutions. The size of the comments varies from half a page to six pages, with one to two pages being the most typical.

One overall comment is that most of the institutions on a general level support the development of a national qualifications framework. The main argument put forward is that a qualifications framework based on descriptors of learning outcomes will secure the progression between the cycles. Just a few of the institutions mentioned mobility and employability as an important aspect of the framework.

Many of the institutions, however, questioned the possibility of developing a framework that fits all types of higher education. For instance, the two institutes of arts and the Academy of Music argued that the terminology and definitions used in the proposal do not correspond with what counts as knowledge and competence in fields such as art and music. Many of the institutions remarked that there is a risk that a too-detailed and standardized structure would be quite problematic concerning institutional autonomy. As Oslo University College points out, on the one hand there is a danger that the descriptors, in order to include the diversity of programmes, become meaningless. On the other hand, if the descriptors become too detailed there will be no room for taking the uniqueness of the different programmes into account. Furthermore, some of the institutions thought it a problem that the proposal follows the EQF format and not the Dublin Descriptors. For

\begin{tabular}{|c|c|c|c|}
\hline & Knowledge & Skills & $\begin{array}{l}\text { Competence (in terms of responsibility } \\
\text { and autonomy) }\end{array}$ \\
\hline $\begin{array}{l}\text { 1. Cycle } \\
\text { (Bachelor } \\
\text { degree) }\end{array}$ & $\begin{array}{l}\text { Have knowledge of central themes } \\
\text { and issues in the field of study }\end{array}$ & $\begin{array}{l}\text { Be able to apply the knowledge } \\
\text { of the field of study to practical } \\
\text { as well as theoretical problems }\end{array}$ & $\begin{array}{l}\text { Be able to plan and implement } \\
\text { work tasks within a given time } \\
\text { frame }\end{array}$ \\
\hline $\begin{array}{l}\text { 2. Cycle } \\
\text { (Master } \\
\text { degree) }\end{array}$ & $\begin{array}{l}\text { Have broad, general knowledge } \\
\text { within the subject/discipline and } \\
\text { in-depth knowledge within a } \\
\text { defined area }\end{array}$ & $\begin{array}{l}\text { Be able to apply their knowledge } \\
\text { and understanding to problem } \\
\text { solving in an independent way }\end{array}$ & $\begin{array}{l}\text { Be able to take on an independent } \\
\text { responsibility for further } \\
\text { competence development and } \\
\text { specialisation }\end{array}$ \\
\hline $\begin{array}{l}\text { 3. Cycle } \\
\text { (PhD } \\
\text { degree) }\end{array}$ & $\begin{array}{l}\text { Have knowledge about the } \\
\text { research frontier of the field } \\
\text { of study }\end{array}$ & $\begin{array}{l}\text { Be able to analyse complex } \\
\text { questions within the field of study } \\
\text { and extend and redefine existing } \\
\text { knowledge }\end{array}$ & $\begin{array}{l}\text { Be able to participate in scholarly } \\
\text { debates within the field of study } \\
\text { on an international scene }\end{array}$ \\
\hline
\end{tabular}


instance, Tromsø University College argues that it is difficult to make a clear distinction between knowledge, skills and competence due to the fact that they are not mutually exclusive (Høringsuttalelser til nasjonalt rammeverk for kvalifikasjoner 2007). Additionally, as the Norwegian University of Life Sciences points out, the relationship between the national framework, the EQF and the Dublin Descriptors is rather unclear and an explicit description of the relationship is needed. The use of competence as a category instead of attitudes [holdninger] is also questioned by some of the institutions. Finally, many of the comments also include suggestions for changes in the descriptors or to add new descriptors. These comments are rather detailed and relate to specific institutional interests.

I will sum up this section by two conclusions. First, despite general support for the idea of a framework, the institutions have doubts about its validity if it is to be relevant and accurate for all types of educational programmes. In other words, the institutions question what Ensor labels as the "one-size-fits-all" approach (Ensor 2003, p. 344). Second, the institutional responses, with a few exceptions, do not connect their arguments and comments to the Bologna process and the development of a European Higher Education Area. The relevance of a qualifications framework is first and foremost seen as an internal instrument to secure progression between the different cycles.

In the next section I will turn to how the policy for qualifications frameworks can be understood in the light of curriculum theory. Qualifications frameworks have implications for how knowledge and competences are framed and articulated in higher education. A key question in the field of curriculum studies is how to understand knowledge. For this reason curriculum theory can illuminate aspects of how to perceive the idea and intentions of qualifications frameworks.

\section{THE PURSUIT OF A NEW CURRICULUM APPROACH FOR EUROPEAN HIGHER EDUCATION?}

Curriculum as a field of study has not played a central role in the research literature in higher education in Europe. However, as higher education institutions have expanded (mass education) and become more complex, the planning of these institutions, and thereby the management of the curriculum, has come to be seen as rather important. In other words, higher education seems to develop in similar ways to general education. In order to analyse the curriculum approach on which the qualifications frameworks and the vision of the new architecture of higher education are based, conceptual frameworks and approaches to curriculum that have been developed for general education may help us to understand the main issue.

One point of departure is Alistair Ross's (2000) description of four competing curriculum models or forms. These four forms rest upon different sets of assumptions about the purpose and function of education. The first model is a content-driven curriculum where the academic disciplines represent the core knowledge and the knowledge of greatest importance. The second form is the learner centred or process-driven curriculum where the experiences and interests of the learner are at the forefront. A utilitarian or objectives-driven curriculum is the third model where the underlining argument is that the structure and the content of education must be directly relevant to the needs of society and, as Ross points out, in particular, to the needs of employers. In the fourth form, the curriculum is less classified and is rather based on an eclectic mixture of different ideas. In similar ways, while aiming to discuss the relationship between curriculum approaches and knowledge, Rob Moore and Michael Young (2001) argue that there are two dominant sets of assumptions about knowledge and the curriculum, which they describe as "neo-conservative traditionalism" and "technical instrumentalism". The first kind represents an assumption that the curriculum is a given body of knowledge that should be transmitted to the students. This is in line with Ross's content-driven curriculum. The second kind, technical instrumentalism is based on the assumption that the imperative of the curriculum is to support the needs of the economy. Again, this assumption fits with Ross's third form, the utilitarian objectives-driven curriculum.

The educational context for Ross as well as for Moore and Young is the U.K. For an understanding of the historical roots of learning objectives and the importance of learning outcomes, a short visit to the curriculum field in the USA also seems necessary. Ralph Tyler has been described as the most influential figure in the field of curriculum in the USA and his book entitled Basic Principles of Curriculum and Instruction (1949) has been viewed as the most powerful educational text ever written (Pinar et al. 1995). Central to his approach are the identification and selection of educational objectives, the selection of learning experiences and the evaluation of the educational program (Tyler 1975/1988). His aim was to develop a rational, scientific and procedural process of curriculum development, which puts the development of educational objectives to the fore. According to Pinar et al. (1995), the second most influential text, which to some extent followed the scientific and technical approach of Tyler, is Benjamin Bloom's The Taxonomy of Educational Objectives, Handbook 1: The Cognitive Domain (1956). This book aimed for greater precision in the communication of educational objectives (Krathwohl 1964/1988). Originally, learning outcome statements were characterised by the use of active verbs, expressing categories as knowledge, comprehension, application, analysis, synthesis and evaluation (Bloom et al. 1956). Furthermore, these categories were intended to be 
hierarchical in order, arranged along a continuum of internalization from lowest to highest (Krathwohl et al. 1964). Through the work of Bloom and followers, behavioural objectives became preferred. According to Pinar et al., "Behavioural objectives established measurable goals and outcomes for curriculum, a means for quantifying these outcomes" $(1995,165)$. Although the taxonomies and the emphasis on behavioural objectives have been heavily criticised (for example Eisner 1969, 1979, Elliott 1998, Pinar et al. 1995), Bloom's taxonomy is used as a reference point in the proposed Norwegian national qualification framework presented above.

One of the studies of curriculum in higher education I find particularly relevant for the debate on the European national qualifications framework is Paula Ensor's (2004) study of four different curriculum discourses in an article on higher education reforms in South Africa in the 1990s. Central to her analysis is the tension between the traditional disciplinary discourse and the newly developed credit exchange discourse or credit accumulation and transfer discourse. The new discourse has, in contrast to the traditional disciplinary discourse, a projective orientation towards the global world, and it underlines the importance of students' choices. A key characteristic of the discourse is modularisation of the curriculum and descriptions of modules in terms of outcomes that can be matched and exchanged as part of a process of accumulating credit towards academic qualifications. According to its supporters, restructuring the curriculum in line with such an approach involves a shift from subject-based teaching to student-based teaching, where the teacher is a "facilitator rather than expert". Furthermore, the focus should be on competence or generic skills rather than knowledge or content. "In other words", Ensor continues, "the vertical pedagogic relations associated with academic apprenticeship into domain-specific knowledge favoured by a disciplinary discourse are to be eschewed" (Ensor 2004, p. 347).

Moving back to the policy documents we may argue that the underlying curriculum assumption represents a critique of a contentdriven curriculum approach. The underlying text of the documents advocates a shift from a content-based approach to a learning outcome approach. It is stated that the focus on learning outcomes represents a change from teaching to learning and a shift from a traditional teacher-centred approach to a student-centred approach (Bologna Working Group on Qualifications Frameworks 2005, p. 38). Consequently, the new forms of curriculum management in higher education put forward by the Bologna process represent values and visions that challenge an academic contentdriven curriculum based on an understanding that it is the teachers, due to their formal research qualification, who should be in charge of the content and pedagogy of the programme. Implicitly, one senses a critique of the traditional disciplinary-based curriculum as having limited relevance to students' interests and the requirements of the labour market. Ensor (2004) argues that the specification of learning outcomes is not first of all an effort to address issues of quality. It is an attempt to provide a mechanism to facilitate the circulation of knowledge in an organised framework. The descriptions of learning outcomes within a credit transfer framework become the national and European currency that enables students and graduates to circulate in a predictable system. The Norwegian proposal argues that the aim of a qualifications framework is to "systematise diversity". At the same time it asks for standardisation in order to manage a higher education system that emphasises universal participation as well as employability, mobility and competitiveness.

There are differences between the process of the development of qualification frameworks in higher education in Europe and the process of the development of educational taxonomies in the 1950s and 1960s in the USA. Still, there are similarities and hence some lessons to be learned with respect to the idea of defining learning outcomes through behavioural objectives (for example Bloom et al. 1956; Krathwohl et al. 1964). The objective-oriented curriculum has been criticised by many (Eisner 1969, 1979, Elliott 1998). Elliott argues that "By standardizing and predetermining learning outcomes "objectives" inhibit the expression of individuality and creativity of learning, and thereby prevent young people from personally appropriating culture as a resource for making sense of their experience" (Elliott 1998, p. xiv).

Skjervheim, a significant critical contributor to the Norwegian university debate in the 1960s and 1970s, offered some strong arguments against instrumentalism, which are highly relevant regarding recent trends in higher education. Skjervheim (1976/1996) asked for a student to be a participant in higher education. In order to take that role, higher education must be a space for discussion, engagement and commitment. In Skjervheim's view the spectator interprets somebody else's assertion as a matter of fact, which means that discussion has no function. The participant in contrast, he argues, interprets somebody else's assertion as just that - an assertion - which makes her get involved in the discussion. Skjervheim argues that “From a participant's point of view nothing is predetermined. One shall just therefore get involved and decide the course of events, determine" (Skjervheim 1996, p. 80) [author's translation and italics]. In my view, the underlining assumption behind the ideology of an outcome-based curriculum is precisely that education should be predetermined.

Another way of questioning the idea of national frameworks based on common descriptors for different programmes of higher education is to highlight the distinctiveness of different disciplines 
and professional fields (Becher 1989, 1994, Neumann et al. 2002, Stark and Lattuca 1997). While Tony Becher focuses on disciplinary differences, Joan S. Stark and Lisa R. Lattuca describe the differences between professional fields. Becher's argument is that a disciplinary group can be regarded as a tribe, with its own set of intellectual values and its own area of cognitive territory. Consequently, disciplinary cultures and the nature of knowledge must have consequences for the curriculum. He argues that although there are certain principles in common for all disciplinary fields when it comes to the curriculum, there are also important differences. An objectivesbased curriculum approach may fit easily in a professional subject with clear-cut requirements, while on a course which depends on an integrative understanding of complex interrelationships it may become rather difficult (Becher 1994).

In other words, we may question whether the idea of a qualifications framework takes the distinctiveness of sites of learning or epistemological constraints into account. According to Young, qualifications depend on trust, not just rules, law or criteria, but, as he argues, "it is far from clear what the new communities of trust will be that will underpin the emerging frameworks once subjects, disciplines, crafts and trades have disappeared or become marginalized" (2003, p. 235). When reading the policy documents it becomes certainly clear that knowledge is an important political issue; however, we may question whether the pursuit of a new architecture of higher education in Europe disconnects itself from the discussion of knowledge on the institutional level where the distinctiveness of the educational fields (hard-soft, pure-applied or professional-academic etc.) traditionally constitutes the important markers for curriculum development in higher education.

\section{CURRICULUM POLICY AND ITS IMPACT ON CURRICULUM PRACTICE}

As recognized among researchers (Goodlad 1979, 1988, Davis 1998), curriculum developments in practice rarely follow the rhetoric of change proposed by the system of governance. Rhetoric may not accord with reality. Reforms, therefore, have never worked as they were portrayed (Davis 1998). As the neo-institutional theory argues, an organisation is placed within institutional environments where it is confronted with social norms and conventions about how the organization should look and behave. How an institution will act and pick up a reform depends on the nature of existing institutionalized practices (Gornitzka 2007, p. 158). Johan P. Olsen (2007, p. 45) argues that although universities have never

fully controlled their direction, substance or speed of development ... developments have not merely reflected functional responses to macro-forces and national styles, educational ideals and cultures, or differentiation within science itself. The University has been influenced, but not determined, by their environments and we have to consider to what degree reformers promoting specific programs and visions of higher education have had an impact.

The Stocktaking Reports and the Trends Reports, as well as reports from a variety of Bologna follow-up meetings, tell us that there are some challenges and problems in attempts to develop national frameworks that follow the main ideas and reference points of the European frameworks and at the same time make sense within a national context. Despite all the difficulties they describe, these reports still convey a strong conviction that qualifications frameworks will be successfully implemented in the end. The underpinning assumption is that implementation is a rational process where it is possible to overcome obstacles by developing plans and strategies that involve different stakeholders in the process. The difficulties are not seen as fundamental; there are misunderstandings, confusions and lack of clarifications that can be dealt with through a vigilant planning process.

There is no empirical evidence put forward in this article to conclude about curricular effects of qualifications frameworks on an institutional level. However, according to the responses from the higher education institutions to the Norwegian proposal on a national qualifications framework, some of the reservations are based on conflicting norms and observed contradictions rather than misunderstandings. Although the term architecture may give an impression that there is something rather clear and materialised, there is a considerable distance between the rhetoric and catchphrases of the documents and the actual development of institutional practices (Olsen and Maassen 2007).

It is rather clear that there are tensions and contradictions within the different documents and among the different stakeholders when it comes to the main aims and functions of qualifications frameworks. The process of implementation will almost certainly reflect the ambiguity of the policy. On the one hand, a qualifications framework can be viewed as an instrument of regulation and quality control (Young 2003) indicating a rather strong framework. On the other hand, a qualifications framework can also be seen as an instrument of communication (Young 2003) which provides a guide to learners about what to choose as well as a guide to employers concerning who to choose. It is not clear in which direction the development of national qualifications frameworks is moving. Although it is argued in some of the documents that it is essential to recognise that the national frameworks of qualifications are "dynamic structures that need to develop as the national situation and priorities change" (Bologna 
Working Group on Qualifications Framework 2005, p. 38), it also holds true that a common national qualifications framework for higher education represents a standardisation where all qualifications of importance need to fit within the columns.

\section{CONCLUSIONS}

The purpose of this article is to analyse the development of European qualifications frameworks for higher education and thereby contribute to a debate about the curriculum assumptions that the idea of a qualification framework is based on. One conclusion to draw is that two years before the deadline of the Bologna process the architecture of a qualifications framework is still not well implemented.

With reference to curriculum theory on general education, the attempt to develop qualifications frameworks at a national level and on a European level fits well with an objectives-driven curriculum model based on a strong utilitarian ethos. The disciplinary or content-driven curriculum model has been criticised for not providing students with sufficient preparation for the labour market (see, for instance, Commission of the European Communities 2006, pp. 6-7). The idea of qualifications frameworks based on measurable learning outcomes represents a turn towards an instrumental curriculum approach in higher education. Such an instrumental view of education stands in a sharp contrast to Humboldt's ideals of seeing intellectual institutions as having a call to "devote themselves to the elaboration of the uncontrived substance of intellectual and moral culture, growing from a uncontrived inner necessity" (Humboldt 1970, p. 243). But it is also in contrast to the values of scholars in the field today. Ronald Barnett (2003) states that higher education institutions should create a space that praises critical disagreement as well as critical reflection. Higher education must therefore be open to multiple understandings. From a somewhat different theoretical framework, Delanty (2001) argues that the university has to take a critical and hermeneutic role in the orientation of cultural models and act as a site of public debate. Furthermore, as Solbrekke (2007) argues, if the normative claim of higher education is to foster civic engagement and societal responsibility, then higher education institutions must create learning spaces that encourage deliberative communication in which students and teachers can come together and discuss the implications of intellectual development in terms of societal engagement. This may stimulate an education not only restricted to formal knowledge, but where disciplinary knowledge is combined with moral and societal reflections in an unpredictable way.

As this article shows, many reports have been written, lots of meetings have been held and many decisions have been taken; however, higher education institutions are difficult to change. Only the future will show whether the qualifications frameworks will move educational practice in higher education towards a new instrumentalism that fits with larger discursive forces towards market orientation or whether it ends up as a story about "Much Ado about Nothing". Most likely, institutions will adapt to the language of qualifications frameworks and follow some new structures, yet define their own solutions. At the departmental level, the academics will continue to ask "What should we teach?" and curriculum is still seen as "an organization of knowledge involving the selection of content and also structuring of the relationship within the content" (Moore 2004, p. 147).

\section{REFERENCES}

Adam, Stephen (2007): Report Based on the Analysis of Individual Country 2007 Stocktaking Submissions on the Implementation of National Qualifications Frameworks. Strasbourg: Council of Europe Higher Education Forum on Qualifications Frameworks.

Barnett, Ronald (2003): Beyond All Reason. Living with Ideology in the University. Buckingham: Society for Research into Higher Education \& Open University Press.

Becher, Tony (1989): Academic Tribes and Territories. Milton Keynes: Society for Research into Higher Education and Open University Press.

Becher, Tony (1994): The significance of disciplinary differences. Studies in Higher Education, 19(2), 151-161.

Bergen Communiqué (2005): The European Higher Education Area-Achieving the Goals. Communiqué of the Conference of Ministers responsible for Higher Education, Bergen, 19-20 May.

Berlin Communiqué (2003): Realising the European Higher Education Area. Communiqué of the Conference of Ministers responsible for Higher Education, Berlin, 19 September.

Bloom, Benjamin; Englehart, Max D.; Furst, Edward; Hill, Walker H. \& Krathwohl, David R. (1956): Taxonomy of Educational Objectives. The Classification of Educational Goals, Handbook 1: Cognitive Domain. New York: David McKay Company.

Bologna Declaration (1999): Joint Declaration of the European Minister of Education. Bologna 19 June.

Bologna Process (2007): Bologna Process Stocktaking Report. London: Department for Education and Skills, <http://www.dfes.gov.uk/londonbologna/ uploads/documents/6909-BolognaProcessST.pdf> (accessed 7 March 2008).

Bologna Working Group on Qualifications Frameworks (2004): A Framework for Qualifications of the European Higher Education Area. Copenhagen: Ministry of Science Technology and Innovation.

Bologna Working Group on Qualifications Frameworks (2005): A Framework for Qualifications of 
the European Higher Education Area. Copenhagen: Ministry of Science Technology and Innovation, <http://www.bologna-bergen2005.no/Docs/00Main_doc/050218_QF_EHEA.pdf> (accessed 7 March 2008).

Bologna Working Group on Qualifications Frameworks (2007): National Qualifications Frameworks Development and Certification. Final report. London: Department for Education and Skills, <http://www.dfes.gov.uk/londonbologna/uploads/ documents/WGQF-report-final2.pdf > (accessed 7 March 2008).

Commission of the European Communities (2006): Delivering on the Modernisation Agenda for Universities: Education, Research and Innovation. Communication from the Commission to the Council and the European Parliament, Com (2006) 208 Final, Brussels.

Crosier, David; Purser, Lewis \& Smidt, Hanne (2007): Trends V: Universities Shaping the European Higher Education Area. Brussels: European University Association, <http://www.eua.be/ fileadmin/user_upload/files/Publications/EUA_ Trends_V_for_web.pdf> (accessed 7 March 2008).

Davis, O.L. (1998): The theoretical meets the practical: the practical wins. In Bjørg B. Gundem and Stefan Hopmann (eds): Didaktik and/or Curriculum. An International Dialogue, pp. 87-106. New York: Peter Lang.

Delanty, Gerard (2001): Challenging Knowledge. The University in the Knowledge Society. Buckingham: Society for Research into Higher Education \& Open University Press.

Eisner, Elliot W. (1969): Instructional and expressive educational objectives: their formulation and use in curriculum. In W. James Popham (ed.): Instructional Objectives, pp. 1-31. Chicago: Rand McNally Company.

Eisner, Elliot W. (1979): The Educational Imagination: On the Design and Evaluation of School Programs. New York: Macmillan.

Elliott, John (1998): The Curriculum Experiment. Buckingham: Open University Press.

Ensor, Paula (2003): The national qualifications framework and higher education in South Africa: some epistemological issues. Journal of Education and Work 16(3), 325-346.

Ensor, Paula (2004): Contesting discourses in higher education curriculum restructuring in South Africa. Higher Education 48(3), 339-359.

European Council (2004): Education \& Training 2010. The Success of the Lisbon Strategy Hinges on Urgent Reforms. Joint interim report of the Council and the Commission on the implementation of the detailed work programme on the followup of the objectives of education and training systems in Europe, 14358/03 EDUC 168-COM (2003) 685 final, <http://ec.europa.eu/education/ policies/2010/doc/jir_council_final.pdf> (accessed 7 March 2008).

Goodlad, John (1979): Curriculum Inquiry: The Study of Curriculum Practice. New York: McGraw-Hill.

Goodlad, John (1988): What some schools and classrooms teach. In J. Gress and D.E. Purpel (eds): Curriculum: An Introduction to the Field, 2nd ed., Berkeley: McCuthan Publishing Corporation, pp. 337-356.

Gornitzka, Åse (2007): The Lisbon Process: A supranational policy perspective. In Peter Maassen and Johan P Olsen (eds): University Dynamics and European Integration, pp. 155-178. Dordrecht: Springer.

Høringsuttalelser til nasjonalt rammeverk for kvalifikasjoner [Statements from hearings concerning a national framework for qualifications] (2007): Kunnskapsdepartementet, <http:// www.regjeringen.no/nb/dep/kd/dok/hoeringer/ hoeringsdok/2007/Horing-av-forslag-til-nasjonaltkvalifik/Horingsuttalelser/Horingsutalelser-medmerknader.html id=476443 $>$ (accessed 7 March 2008).

Humboldt, Wilhelm von (1970) [1809/1810]: On the spirit and the organisational framework of intellectual institutions in Berlin. Minerva 8, pp. 242-250.

Krathwohl, David R. (1988) [1964]: The taxonomy of educational objectives-its uses in curriculum building. In James R. Gress and David E. Purpel (eds): Curriculum: An Introduction to the Field, 2nd ed., pp. 259-275. Berkeley: McCuthan Publishing Corporation.

Krathwohl, David R.; Bloom, Benjamin S. \& Masia, Bertram (1964): Taxonomy of Educational Objectives. The Classification of Educational Goals, Handbook II: Affective Domain. New York: David McKay Company.

London Communiqué (2007): Towards the European Higher Education Area: Responding to Challenges in a Globalised World. Communiqué of the Conference of Ministers responsible for Higher Education, London 18 May.

Moore, Rob (2004): Education and Society. Cambridge: Polity Press.

Moore, Rob and Young, Michael (2001): Knowledge and the curriculum in the sociology of education: towards a reconceptualisation. British Journal of Sociology of Education 22(4), 445-461.

Neumann, Ruth; Parry, Sharon \& Becher, Tony (2002): Teaching and learning in their disciplinary contexts: a conceptual analysis. Studies in Higher Education 27(4), 405-417.

Olsen, Johan P. (2007): The institutional dynamics of the European university. In Peter Maassen and Johan P. Olsen (eds): University Dynamics and European Integration, pp. 25-53. Dordrecht: Springer. 
Olsen, Johan P. \& Maassen, Peter (2007): European debates on the knowledge institution: the modernization of the university at the European level. In Peter Maassen and Johan P. Olsen (eds): University Dynamics and European Integration, pp. 3-22. Dordrecht: Springer.

Pinar, William F.; Reynolds, William M.; Slattery, Patrick \& Taubman, Peter M. (1995): Understanding Curriculum. New York: Peter Lang.

Rapport fra en arbeidsgruppe (2007): Forslag til Nasjonalt rammeverk for kvalifikasjoner i Høyere utdanning, Kunnskapsdepartmentet [Report from a working group. Proposition to a national framework for qualifications in higher education]. <http://www.regjeringen.no/Upload/KD/ Hoeringsdok/2007/200703620/Rapport_Forslag_ til_nasjonalt_rammeverk_for_kvalifikasjoner_i_ hoeyere_utdanning.pdf.pdf> (accessed 12 March 2008).

Ross, Alistair (2000): Curriculum. Construction and Critique. London: Falmer Press.
Skjervheim, Hans (1996) [1976]: Deltakar og tilskodar og andre essays [Participant and spectator and other essays]. Oslo: Ashehoug.

Solbrekke, Tone D. (2007): Understanding Conceptions of Professional Responsibility. Doctoral dissertation. Series dissertation submitted to the Faculty of Education, University of Oslo No. 88.

Stark, Joan S. \& Lattuca, Lisa R. (1997): Shaping the College Curriculum. Academic Plans in Action. Boston: Allyn and Bacon.

Tyler, Ralph W. (1949): Basic Principles of Curriculum and Instruction. Chicago: The University of Chicago Press.

Tyler, Ralph W. (1988) [1975]: Specific approaches to curriculum development. In James R.Gress and David E. Purpel (eds): Curriculum: An Introduction to the Field. 2nd ed., pp. 219-234. Berkeley: McCutchan Publishing Corporation.

Young, Michael (2003): National qualifications frameworks as a global phenomenon: a comparative perspective. Journal of Education and Work 16(3), 223-237. 